\title{
KAJIAN LITERATUR RESISTENSI DALAM PENGAMBILAN KEBIJAKAN PEMBANGUNAN SERTA USULAN STRATEGI DALAM MENGHADAPI RESISTENSI KEBIJAKAN PEMBANGUNAN OLEH PEMERINTAH KABUPATEN INDRAGIRI HILIR
}

\author{
Akbar Alfa ${ }^{1}$, Rezky Kinanda² \\ ${ }^{1}$ Direktur SDGs Study Center UNISI, Universitas Islam Indragiri \\ ${ }^{2}$ Dosen Prodi Teknik Sipil Fakultas teknik dan ilmu Komputer Universitas Islam Indragiri. \\ Email: alfa.boyone@gmail.com (correspondensi)
}

\begin{abstract}
The Resistance Movement is a movement that is very typical of the rejection of policies or changes made in an area in which there are humans in it. There are two categories of actors involved in the resistance movement, namely the policy maker and the recipient of the policy. The identity of the perpetrators depends on the case and the location of the case which contains different human characteristics or human communities. The research uses literature review as preparation material for the Government of Indragiri Hilir Regency in dealing with resistance movements.

This journal is the result of qualitative research which will explain theoretically the resistance movement. Resistance movement is the movement of a party in making a rejection or resistance to the policy to be made or already made. The results of this study can be used as a discussion of Indragiri Hilir Regency Government in making policies and dealing with resistance movements.

This research concludes that poor communication and socialization can spark a desire to resist. The resistance movement becomes stronger when the policy maker is unable or slow in responding to the complaints of the recipient of the policy. Regardless of whether the complaint is wrong or right, rapid response must be done quickly so that there is no misunderstanding that causes greater resistance. The policy makers must identify the causes of resistance because the causes are the basic foundation in developing strategies for handling and resolving conflicts in this resistance movement. So that it can be said that each cause has its own handling strategy.
\end{abstract}

Keywords: Resistance Movement, Policy Makers, Policy Recipients, Communication, resistance.

\begin{abstract}
Abstrak
Gerakan Resistensi adalah gerakan yang sangat khas kepada penolakan terhadap kebijakan atau perubahan yang dilakukan di suatu wilayah yang di dalamnya terdapat manusia-manusia di dalamnya. Pelaku yang terlibat dalam gerakan resistensi secara garis besar ada dua kategori yaitu pihak pembuat kebijakan dan pihak penerima kebijakan. Adapun identitas para pelaku tergantung kasus dan lokasi kasus yang di dalamnya mengandung karakteristik manusia atau komunitas manusia yang berbeda-beda. Adapun penelitian ini menggunakan kajian pustaka sebagai bahan persiapan untuk Pemerintah Kabupaten Indragiri Hilir dalam menghadapi gerakan resistensi.

Jurnal ini adalah hasil penelitian kualitatif yang akan menerangkan tentang gerakan resistensi secara teoritis. Gerakan resistensi adalah gerakan suatu pihak dalam melakukan penolakan atau perlawanan terhadap kebijakan yang hendak dibuat atau sudah dibuat. Hasil dari penelitian ini bisa dijadikan bahas pertimbangan Pemerintah Kabupaten Indragiri Hilir dalam membuat kebijakan dan menghadapi gerakan resistensi.

Penelitian ini menghasilkan kesimpulan bahwa komunikasi dan sosialisasi yang buruk dapat mencetuskan hasrat untuk melakukan resistensi. Gerakan resistensi semakin kuat manakala pihak pembuat kebijakan tidak mampu atau lamban dalam merespon keluhan pihak penerima kebijakan. Terlepas dari keluhan tersebut salah atau benar, tindakan cepat tanggap harus
\end{abstract}


cepat dilakukan agar tidak terjadi kesalahpahaman yang menyebabkan resistensi semakin besar. Pihak pembuat kebijakan harus mengidentifikasi penyebab resistensi dikarenakan faktor penyebab menjadi pondasi dasar dalam menyusun strategi penanganan dan penyelesaian konflik dalam gerakan resistensi ini. Sehingga bisa dikatakan setiap penyebab memiliki strategi penanganan sendiri.

Kata Kunci: Gerakan Resistensi, Pembuat Kebijakan, Penerima Kebijakan, Komunikasi, perlawanan.

\section{Pendahuluan}

Diketahui bahwa pembangunan adalah Suatu usaha atau rangkaian usaha pertumbuhan dan perubahan yang berencana dan dilakukan secara sadar oleh suatu bangsa, negara dan pemerintah, menuju modernitas dalam rangka pembinaan bangsa. (Siagian, 1994). Pembangunan sendiri adalah hal yang sudah awam di masyarakat sebagai salah satu usaha untuk membawa kehidupan menjadi lebih baik.

Adapun pembangunan amat sangat lekat dengan kebijakan. Bahkan kebijakan untuk tidak melakukan suatu produk pembangunan pun bisa dianggap sebagai kebijakan pembangunan manakala kebijakan tersebut ditujukan untuk mendapatkan manfaat yang jauh lebih besar.

Kebijakan sendiri adalah adalah Serangkaian tindakan yang mempunyai tujuan tertentu yang diikuti dan dilaksanakan oleh seorang pelaku atau sekelompok pelaku guna memecahkan suatu masalah tertentu (James, 2003). Kebijakan sendiri amat sangat terikat pada siapa sang pengambil kebijakan, hal ini dikarenakan kebijakan yang diambill oleh orang yang berkuasa maka akan menghasilkan kebijakan yang sangat kuat. Dan dalam hal pembangunan pengambil kebijakan adalah pemerintah yang menjabat. Sehingga manakala pemerintah membuat sebuah kebijakan pembangunan maka kebijakan tersebut akan menghasilkan dampak yang besar.

Salah satu hal yang sangat lekat dengan kebijakan pembangunan adalah resistensi. Hal ini dikarenakan kebijakan pembangunan adalah ranah dimana masyarakat menjadi aspek terdekat sebagai penerima produk kebijakan pembangunan dan kompleksitas di masyarakat menjadi pembangkit gairah resistensi.

Dari segi bahasa resistensi adalah "perlawanan atau menentang". Berasal dari bahasa Inggris yaitu resist. Dalam hal ini yang dimaksud adalah semua tindakan yang menolak atau melawan. Resistensi terhadap kebijakan pemerintah artinya merupakan penolakan terhadap kebijakan pemerintah.

Di Indonesia kebijakan pembangunan sering berhadapan langsung dengan resistensi dari masyarakat. Terlepas dari kebijakan tersebut benar atau salah. Resistensi masyarakat sendiri bisa berdampak baik manakala segala inti materi dari resistensi masyarakat bisa tersampaikan dan menjadi pertimbangan kebijakan. Buruknya adalah manakala materi dari resistensi tersebut tidak mampu disampaikan dengan baik dan benar lalu gagal menyentuh area pertimbangan kebijakan sehingga tidak mampu mempengaruhi kebijakan dari pemerintah.

Di Kabupaten Indragiri Hilir sendiri telah terjadi beberapa kasus penolakan masyarakat terhadap kebijakan pemerintah. Seperti penolakanan pembangunan rumah ibadah, pencabutan izin guna lahan, dan kebijakan-kebijakan lainnya. Sebagai contoh adalah kebijakan Pemerintah Kabupaten Indragiri Hilir untuk tidak memperbaiki jalan dengan status provinsi dan Negara sebagai bentuk ketaatan terhadap hukum Negara, masyarakat yang tidak mengetahui hakikat dari kebijakan tersebut justru secara tidak sadar menolak kebijakan tersebut. Masyarakat yang tidak memiliki pengetahuan akan hal ini beranggapan seluruh jalan di Kabupaten Indragiri Hilir adalah tanggung jawab Pemerintah Kabupaten. Resistensi masyarakat yang tidak ditangani dengan baik mau tidak mau berdampak negative kepada Pemerintahan Kabupaten Indragiri Hilir.

Penelitian ini akan mencoba menemukan dan menggali lebih jauh mengenai gambaran proses resistensi yang di dalamnya menjelaskan penyebab resistensi, dampak dampak resistensi, aktor resistensi, serta implikasi resitensi pada kebijakan pembangunan. Hal ini guna memahami strategi-strategi untuk menangani resistensi 
kebijakan pembangunan khususnya di Kabupaten Indragiri Hilir umumnya untuk seluruh lapisan pemerintahan. Hasil dari penelitian ini bisa dijadikan bahas pertimbangan Pemerintah Kabupaten Indragiri Hilir dalam membuat kebijakan dan menghadapi gerakan resistensi.

\section{Metode Penelitian}

Permasalahan yang akan dikaji oleh peneliti merupakan masalah yang bersifat sosial dan teoritis. Oleh karena itu, peneliti memilih menggunakan metode penelitian deskriptif kualitatif dengan kajian literatur untuk menentukan mengolah dan menganalisis teori dari para ahli. Metode penelitian ini dapat digunakan untuk memahami permasalahan secara teoritis.

\section{Metode Pendekatan}

Peneliti menyusun metodologi yang akan ditempuh sebagai alat agar menghasilkan hasil analisis yang bisa memenuhi sasaran yang telah ditentukan. Dalam penelitian ini digunakan metode kualitatif dengan studi literatur atau biasa disebut dengan kajian literatur yaitu cara yang dipakai untuk menghimpun data-data atau sumber-sumber yang berhubungan dengan topik yang diangkat dalam suatu penelitian melalui eksplorasi sumber-sumber ilmiah. Sumber ilmiah bisa didapat dari jurnal, buku, dokumentasi, dan pustaka lainnya.

Studi Literatur merupakan penelitian yang dilakukan oleh peneliti dengan mengumpulkan sejumlah buku yang berkaitan dengan masalah dan tujuan penelitian. Teknik ini dilakukan dengan tujuan untuk mengungkapkan berbagai teori-teori yang relevan dengan permasalahan yang sedang dihadapi/diteliti sebagai bahan rujukan dalam pembahasan hasil penelitian (Danial dan Warsiah, 2009)

Studi literatur berhubungan dengan ide, persepsi, pendapat para ahli yang telah berpengalaman dan kesemuanya tidak dapat diukur dengan angka. Adapun teknik pengumpulan datanya adalah dengan tinjauan buku, skripsi, tesis, desertasi, dan dokumen ilmiah lainnya. Adapun sumber yang dipilih akan ditampilkan pada bagian akhir jurnal yaitu daftar pustaka.

\subsection{Teknik Pengumpulan Data}

Adapun hal-hal yang terkait pengumpulan data pada penelitian ini yaitu:

a. Pada penelitian ini peneliti memilih jenis penelitian studi literatur maka dari itu penelitian akan menggali teori dari berbagai sumber.

b. Dalam penelitian ini sumber yang dipilih haruslah bertaraf ilmiah seperti buku para ahli, penelitian yang telah disahkan sebuah perguruan tinggi, serta sumber ilmiah lainnya. Adapun sumber seperti blog dan website yang tidak memiliki kredibilitas atau tidak dapat dipertanggungjawabkan tidak akan menjadi rujukan.

\subsection{Teknik Analisis Data}

Secara umum penelitian ini akan menggunakan analisis kualitatif yaitu studi literatur.

\subsection{Studi literatur}

Studi literatur adalah kajian teoritis dan referensi lain yang berkaitan dengan nilai, budaya dan norma yang berkembang pada situasi sosial yang diteliti, selain itu studi literature sangat penting dalam melakukan penelitian, hal ini dikarenakan penelitian tidak akan lepas dari literatur-literatur IImiah (Sugiyono, 2012 : 291).

Dalam makna yang lebih mudah dimengerti disimpulkan bahwa kajian literatur atau studi pustaka adalah metode yang menekankan pada penelusuran data dan informasi suatu fenomena yang hendak diteliti pada sumber-sumber ilmiah seperti buku, tesis, desertasi, jurnal, dan sumber ilmiah lainnya.

\section{Pembahasan}

Bagian ini akan menguraikan hasil analisis melalui kajian literature tentang gerakan resistensi kebijakan pembangunan serta usulan strategi dalam menghadapi resistensi kebijakan pembangunan oleh Pemerintah Kabupaten Indragiri Hilir.

\subsection{Analisis Konsep Dasar Resistensi}

Konsep tentang resistensi adalah hal yang menarik bagi ilmuan sosial. Resistensi menjadi hal yang banyak diperbincangkan untuk menelaah kasus-kasus agar mudah diamati secara empiris. Bagi para ahli sosial resistensi bersifat kultural sebab resistensi 
muncul melalui ekpresi serta tindakan keseharian masyarakat.

Seperti yang telah dijelaskan sebelumnya, para ahli mayoritas berpendapat bahwa pengertian resistensi adalah artinya penolakan. Tidak terjadi perbedaan pendapat pada pengertian dasar ini. Termasuk juga makna serupa dengan penolakan seperti perlawanan, pertentangan, dan makna lain yang beranonim dengan kata-kata tersebut.

Dari berbagai sumber yang telah ditelusuri maka dapat disimpukan bahwa resistensi pada umumnya akan terjadi apabila ada produk kebijakan yang mengancam nilai yang dipercayai dan diyakini suatu individu atau kelompok. Ancaman tersebut bisa terkategori benar atau salah. Dengan makna lain ancaman yang diyakini ini bisa bermakna adalah sebuah ancaman yang nyata atau hanya sebuah kesalahpahaman yang diyakini oleh individu atau kelompok yang melakukan resistensi.

\subsection{Analisis Penyebab Resistensi}

Menurut Silvio De Bono dalam bukunya Creating Growth from Change terdapat sebab sebab terjadinya resistensi, yaitu :

a. Takut atau khawatir pada hal yang tidak pasti. Perubahan berdampak pada ketidakpastian, dan ketidakpastian adalah hal yang seringkali gagal memberikan rasa aman dan nyaman. Ketidakpastian bermakna ragu dan tidak tahu atas apa yang mungkin akan terjadi. Hal ini mentransfer rasa takut kepada individu tersebut dan melakukan resistensi dipercaya mampu melongsorkan rasa takut tersebut.

b. Takut akan kegagalan. Sebuah kebijakan mungkin menuntut keterampilan dan kemampuan yang tinggi. Resistensi terhadap kebijakan baru kemudian muncul karena orang mengetahui bagaimana operasionalisasinya, sementara mereka merasa tidak memiliki keterampilan cukup.

c. Tidak sepakat dengan kebutuhan akan perubahan. Terjadi perbedaan pemahaman antara pembuat kebijakan dan pelaku resistensi. Pelaku resistensi merasa kebijakan yang diambil adalah sebuah kesalahan dan akan berdampak buruk. d. Takut kehilangan sesuatu yang bernilai. Pelaku resistensi biasanya memiliki naluri mempertahankan nilai yang sedang dimilikinya, sehingga suatu kebijakan yang membawa perubahan secara langsung atau tidak langsung mengancam untuk merebut nilai yang sedang dimilikinya.

e. Tidak mau meninggalkan zona nyaman. Pelaku resistensi yang telah merasa zona nyamannya adalah yang terbaik untuk kehidupannya akan menjadikan zona nyamannya ini sebagai patokan sebuah kebenaran, sehingga walaupun sebenarnya salah tapi jika dia sudah merasa nyaman maka ia akan tetap menolaknya.

f. Merasa segalanya akan baik-baik saja. Tidak sedikit orang merasa yakin bahwa segala sesuatu akan selesai dengan sendirinya, suatu saat, tanpa melakukan apapun. Sehingga kebijakan baru untuk memperbaiki atau membawa kebaikan untuk lingkungannya dianggap sebagai usaha yang siasia dan tidak penting.

g. Ketidakpahaman dan ketiadaan kepercayaan. Pelaku resistensi menolak perubahan atau kebijakan ketika mereka tidak memahami implikasinya dan berpendapat bahwa perubahan hanya akan lebih banyak membebani daripada kebaikan yang dapat didapat. Situasi demikian terjadi apabila tidak ada kepercayaan antara pihak yang mengusulkan perubahan dengan para anggota organisasi.

h. Ketidakberdayaan (inertia). Pelaku resitensi bisa mengalami suatu kondisi ketidakberdayaan pada tingkatan tertentu, dan karenanya mencoba mempertahankan status quo. Perubahan atau kebijakan yang dating memang membutuhkan upaya, bahkan seringkali upaya yang sangat serius, dan kelelahan pun bisa terjadi.

Menurut James Scoot resistensi masyarakat hanya dibedakan menjadi dua 
kategori yaitu resistensi yang disebabkan oleh penyebab secara langsung dan penyebab tidak langsung. Resistensi karena penyebab secara langsung seperti penindasan, ancaman, tekanan, paksaan yang dilakukan oleh tuan tanah, pemerintah, dan penguasa lainnya. Sedangkan penyebab resistensi secara tidak langsung adalah halhal yang merangsang penolakan melalui halhal tidak langsung atau tidak terlihat langsung.

Agocs mengatakan salah satu faktor penyebab individu resistensi terhadap perubahan adalah adanya kekhawatiran akan ketidaktahuan informasi tentang produk kebijakan, pembangunan, perubahan, dll. Menurut Lim dan Loh beberapa penyebab resistensi adalah sebagai berikut:

a. Tidak ingin keluar dari kebiasaan

b. Merasa tidak aman seperti takut dipecat, atau kehilangan jabatan, atau takut kehilangan nyawa.

c. Khawatir keburukan pada kondisi ekonomi

d. Khawatir pada hal yang sebenarnya tidak diketahui dengan jelas

Sonnenberg tahun (1994) menyimpulkan ada 7 sebab orang melakukan resistensi terhadap perubahan atau kebijakan, yaitu:

a. Procastination. Cendrung tidak ingin berubah atau menunda perubahan

b. Lack of motivation. Merasa kebijakan atau perubahan itu tidak akan embawa manfaat atau kebaikan

c. Fear of failure. Takut tidak mampu bersaing, gagal dalam memahami ilmu pengetahuan terkait perubahan atau kebijakannya.

d. Fear of the unkown. Takut akan sesuatu yang tidak diketahui dan merasa nyaman dengan yang diketahui saja

e. ear of loss. Khawatir perubahan atau kebijakan akan menurunkan statusnya, keuatannya, dan nilai dalam dirinya

f. Dislike the innitiator of change. Ketidak percayaan terhadap pelaku kebijakan atau perubahan dengan kata lain tidak percaya kepada kemampuan sang pembuat kebijakan.

g. Lack of communication. Terjadi kesalahpahaman antara pembuat perubahan atau kebijakan dengan masyarakat sebagai terdampak dari perubahan atau kebijakan tersebut

Dari berbagai sumber yang telah digali, maka dapat disimpulkan bahwa penyebabpenyebab lahirnya resistensi amat sangat beragam tergantung kasus yang terjadi di dunia nyata. Intinya adalah pembuat kebijakan harus benar-benar menelusuri penyebab resistensi sebagai dasar perumusan strategi penyelesaian atau penanganan.

Hasil dari penyederhanaan kategori penyebab resistensi adalah :

a. Masyarakat merasa khawatir akan mendapat dampak negatif dari kebijakan terkait. Seperti takut penghasilan berkurang, takut keamanan berkurang, takut kesehatan berkurang, dll. Baik masyarakat memahami dengan benar ataupun salah.

b. Adanya hubungan yang kurang harmonis antara pembuat kebijakan dengan masyarakat baik terkait kebijakan yang ingin diambil maupun diluar kasus yang sedang dihadapi. Seperti pemerintah kurang sosialisasi, pemerintah kurang berkomunikasi dengan masyarakat, dll.

Di kabupaten Indragiri Hilir sendiri penyebab resistensi cukup erat kaitannya dengan faktor latar belakang pendidikan masyarakatnya. Masyarakat seringkali tidak memahami tentang kebijakan yang diambil masyarakat. Ketidakpahaman bisa menyebabkan penolakan atau perlawanan di dalam diri setiap manusia. Selain itu faktor sosialisasi dan komunikasi kepada masyarakat dirasa belum cukup sehingga maysrakat banyak yang tidak tau bahkan tidak peduli sehingga resistensi acap kali tidak bisa diprediksi. Disamping itu tetap harus diwaspadai faktor penyebab lainnya.

\subsection{Analisis Aktor Gerakan Resistensi}

Aktor atau pelaku dalam gerakan resistensi amat sangat menentukan arah gerakan resistensi bahkan penciptaan resistensi itu sendiri. menurut Hosking (2004) aktor resistensi dikategorikan menjadi dua yaitu pelaku aktif yaitu pembuat perubahan dan pelaku pasif yaitu pelaku yang dikenai perubahan atau kebijakan. 
Hal yang sama juga difatwakan oleh Capra (2002). Pembagian itu adalah agen internal dan agen eksternal. Agen internal adalah pelaku yang membuat perubahan atau kebijakan sedangkan pelaku eksternal adalah siapa saja yang berada diluar pelaku internal yang terlibat dalam perubahan atau kebijakan, bahkan jika pihak tersebut adalah bagian dari pemerintah seperti organisasi lain. Pelaku eksternal seperti masyarakat, pemilik modal usaha, komunitas masyarakat, organisasi pemerintahan, dll.

Sehingga dapat disimpulkan bahwa pelaku gerakan resistensi hanya dibagi atas dua yaitu

a. Aktor utama pembuat kebijakan, pembangunan, atau perubahan

b. Aktor utama yang merasa menerima dampak kebijakan tersebut.

c. Aktor Pendukung yang bervariasi tergantung kasus.

Kabupaten Indragiri Hilir memiliki karekteristik yang berbeda dengan masyarakat perkotaan. Faktor pendidikan yang rendah jika dibandingkan dengan masyarakat perkotaan membuat masyarakat berpotensi ditunggangi oknum-oknum yang tidak bertanggung jawab. Hal ini harus menjadi perhatian penting bagi pemerintah agar setiap kebijakan harus memperhatikan hal ini.

\subsection{Analisis Dampak Resistensi}

Telah dapat diipahami di masyarakat bahwa penolakan masyarakat terhadap kebijakan pembangunan sering berdampak pada terjadinya tindak kekesaran, kebencian, dan lain-lain.

Menurut Marcel Boyer (2013) menjelaskan mengenai dampak dari sebuah aktifitas penolakan terhadap kebijakan pemerintah adalah:

a. Dalam hal lingkungan, kemenangan oleh pelaku resistensi di tempat tertentu dapat membuat atau memperburuk masalah di tempat lain.

b. Dalam infrastruktur atau jasa, aktifitas resistensi dapat menyebabkan keterlambatan dalam memenuhi kebutuhan pembangunan atau rencana pembangunan lainnya.

c. Dalam kualitas produk kebijakan publik, dikarenakan pindah dari lokasi resistensi ke tempat yang tidak terjadi resistensi mengakibatkan proyek dipindahkan ke zona tidak cocok atau kualitas rendah.

Menurut Carol Hager (2015) memiliki pandangan sedikit berbeda, Carol Hager berpendapat bahwa resistensi terhadap kebijakan pemerintah memiliki beberapa dampak positif yaitu:

a. Pembentukan jaringan partisipatif dan kelompok politik baru yang memberi media partisipasi masyarakat yang baru.

b. Teknologi ditingkatkan atau inisiatif teknologi baru untuk memberikan solusi terhadap produk yang ditolak

c. Pembangunan Proyek Lingkungan yang lebih baik dari pada produk pembangunan yang sebelumnya direncanakan

d. Berkontribusi untuk demokratisas lembaga atau bahkan perubahan rezim

Kemudian menurut Kate Burningham (2006) menyimpulkan ada 3 (tiga) dampak dari gerakan penolakan terhadap kebijakan pemerintah, yaitu:

a. Resiko konflik, Bentrok, korban jiwa, dan lain-lain

b. Kerugian finansial pihak pemerintah atau swasta yang mewakili pemerintah dalam penyediaan fasilitas yang ditolak masyarakat

c. Membatalkan kebijakan mxmxm pemerintah

Setelah mengumpulkan pendapat para ahli kemudian dapat disimpulkan bahwa dampak resistensi kebijakan pembangunan atau oerubahan adalah sebagai berikut:

a. Dampak Positif

1) Peningkatan sosialisasi dan komunikasi antara pembuat kebijakan dan penerima kebijakan serta partisipasi masyarakat lebih kuat

2) Peningkatan kualitas kebijakan pembangunan setelah adanya tuntutan untuk perbaikan kebijakan

3) Menjaga sosial, ekonomi, dan lingkungan agar lebih terawasi dari kebijakan yang salah

b. Dampak Negatif

1) Terjadi konflik, kekerasan, kerusakan fasilitas, kebencian, bahkan korban jiwa

2) Jika gagal ditangani maka akan bertambah buruk hubungan antara 
pembuat kebijakan dan penerima kebijakan

3) Perlambatan kebijakan bahkan pembatalan kebijakan tanpa adanya pertimbangan

Pemerintah Kabupaten Indragiri Hilir tidak boleh meremehkan dampak yang bisa dihasilkan oleh gerakan resistensi. Salah satu dampak yang berjangka panjang adalah kepercayaan terhadap pemerintah yang rendah lalu berdampak pada pengambilan kebijakan yang sering kali mendapat penolakan. Selain dari dampak-dampak lain yang telah dijelaskan diatas.

\subsection{Analisis Proses dan Bentuk Resistensi}

Gerakan resistensi memiliki bentuk yang tidak selalu sama dalam setiap kasus. Hal ini tentu hal yang lumrah. Semua tergantung kepada karakteristik pelaku resistensi. Masyarakat ekonomi rendah, ekonomi tinggi, berpendidikan rendah, berpendidikan tinggi, atau karakteristik lainnya tentu akan mengekpresikan resistensinya dengan cara yang berbeda.

Kate Burningham (2006) menjelaskan bagaimana bentuk dan proses lahirnya resistensi kebijakan pemerintah:

a. Tahap awal masyarakat mempelajari tentang kebijakan terkait

b. Kemudian masyarakat mulai mempertanyakan kepada pemerintah

c. Setelah tahap mempertanyakan dilakukan apabila jawaban pemerintah memuaskan mereka maka proses kebijakan berjalan normal, namu apabila masyarakat tidak terpuaskan maka tahap selanjutnya akan ditempuh masyarakat

d. Masyarakat melakukan penolakan dalam berbagai bentuk baik dalam bentuk unjuk rasa maupun jalur legal seperti tuntutan hukum

Clare Sounder (2013) turut menjabarkan proses dan bentuk penolakan kebijakan pemerintah yaitu:

a. Proses terbentuknya penolakan bermula dari kegagalan pemerintah merespon aspirasi masyarakat

b. Setalah gagal direspon masyarakat akan melakukan unjuk rasa yang kemudian mereka berkoneksi dengan pihak-pihak lain untuk mencari dukungan. Adapun bentuk resistensi mereka bisa berbentuk unjuk rasa, penuisan artikel atau kabar berita di media, tuntutan hukum, dll.

Marcel Boyer (2013) menjelaskan bagaimana tahapan-tahapan proses setelah resistensi lahir di masyarakat:

a. Berawal dari penolakan masyarakat terhadap kebijakan

b. Kemudian Pemerintah merespon dengan cara yang tidak bisa diterima oleh masyarakat

c. Sehingga masyarakat frustasi lalu melakukan aksi resistensi (penolakan)

Marcel Bowyer (2013) juga menjelaskan jika respon terhadap resistensi dilakukan melalui proses yang baik:

a. Berawal dari penolakan masyarakat terhadap produk kebijakan

b. Kemudian Pemerintah merespon dengan Kebijakan yang bisa diterima dengan baik oleh masyarakat

c. Pemerintah menerima pemberian masukan masyarakat

d. Alternatif lain pun bisa terlaksana seperti misalnya, pemerintah membuka peluang membuat teknologi baru, memberikan insentif pada masyarakat, dll

Menurut Scott terdapat beberapa bentuk resistensi yaitu:

a. Resistensi tertutup adalah resistensi yang sifatnya tidak terang terlihat dipermukaan seperti yaitu mulut ke mulut, fitnah, berhenti memberikan rasa hormat kepada pemerintah.

b. Resistensi semi-terbuka adalah resistensi yang terlihat secara kasat mata seperti protes sosial atau demostrasi

c. Resistensi terbuka adalah bentuk resistensi yang terorganisir, sistematis dan berprinsip. Media yang digunakan dalam resistensi adalah cara-cara kekerasan seperti melempar, memaki, menghina, 
meneriaki, mengucilkan, mencibir, mengancam, dll.

Secara umum berdasarkan kajian teori, gerakan resistensi akan berproses dan terbentuk sebagai berikut :
a. Publikasi kebijakan
b. Pihak pelaksana kebijakan melakukan sosialisasi
c. Masyarakat mengetahui tentang kebijakan
d. Masyarakat melakukan penolakan terhadap kebijakan terkait
e. Apabila sosialisasi tidak dilakukan makan masyarakat akan melakukan penolakan dengan dasar pengetahuan yang mereka miliki saja
f. Pihak pelaksana gagal merespon masyarakat
g. Gerakan penolakan berlanjut Kebijakan tertunda atau dibatalkan
h. penolakan bisa bersifat langsung dengan unjuk rasa, atau lewat media berita, atau melalui jalur tuntutan hukum resmi.

Para ahli tidak mengingat pendapat mereka pada bentuk dan proses resistensi dalam satu skema saja akan tetapi menurut para ahli proses dan bentuk bergantung pada kasus dan karakter masyarakat.

Di Kabupaten Indragiri Hilir sudah terjadi berbagai bentuk resistensi dari yang hanya sekedar mulut ke mulut hingga unjuk rasa sehingga hal ini tidak bisa dianggap remeh oleh pemerintah dikarenakan akan menjadikan kepercayaan terhaap pemerintah rendah lalu berdampak pada pengambilan kebijakan yang sering kali mendapat penolakan.

\subsection{Analisis Strategi Penanganan Resistensi \\ Pendekatan untuk menyelesaikan} sebuah konflik dari gerakan resistensi tentu amat sangat berbeda dengan konflik lain. Dikarenakan konflik resistensi umumnya terjadi antara penguasa dan rakyat yang mana kedudukan mereka di dalam hukum kenegaraan berbeda.

Marcel Boyer (2013) menjelaskan tentang solusi yang dapat ditempuh pemerintah yaitu: a. Analisis sosial ekonomi yang berorientasi pada nilai ekonomi swasta dan keuntungan masyarakat seperti negosiasi ganti rugi.

b. Mengidentifikasi sejumlah lokasi potensial. Pemindahan lokasi bisa menjadi salah satu alternatif ketika tidak ada kesepakatan yang bisa diraih.

c. Negosiasi kompensasi yang dalam hal ini pemerintah pelaksana kebijakan harus mengeluarkan dana lebih

Hank Smith (2014) memberikan masukan untuk melakukan pendekatan sebagai berikut:

a. Guna lahan yang tidak disukai masyarakat dibangun dibangun dekat dengan rute transportasi

b. Fasilitas pendukung dari kebijakan terkait harus diperhatilkan

c. Upaya peningkatan kepercayaan terhadap pemerintah pelaksana kebijakan seperti sosialisasi

d. Politik dan Keberpihakan harus sesuai aturan dan ilmiah

e. Kesamaan pemahaan aktor terkait kesadaran lingkungan

Kate Burningham (2006) menyatakan ada beberapa solusi yang bisa ditepuh untuk merespon gerakan resistensi terhadap kebijakan pemerintah, yaitu:

a. Kompensasi untuk mengurangi biaya masyarakat

b. Berbagi keuntungan finansial dengan masyarakat

c. Teknologi agar dampak negatif bisa minimal

d. Mencari lokasi untuk pemindahan kebijakan jika memungkinkan

e. Istilah 'solusi' otoriter lebih cenderung memperburuk daripada memecahkan masalah

f. Memperbesar keterlibatan masyarakat

David mengusulkan tiga pendekatan yang dapat diterapkan:

a. Force change strategy. Mengutamakan kekuasan pemerintah dan tegas untuk menerapkan atau melaksanakan kebijakan yang bersifat perubahan yang mana 
perubahan itu bersifat wajib. Pendekatan ini memang terkesan memaksa akan tetapi jika diterapkan dengan baik maka ketegasan ini bisa membuahkan hasil yang diinginkan.

b. Educative change strategy. Pendekatan ini dilaksanakan dengan memperkuat lini pendidikan, sosialisasi, diskusi, dan kegiatan lain yang bertujuan mendidik atau memberikan informasi yang benar kepada pelaku resistensi agar mereka tidak menerima informasi yang salah dan resitensi semakin bergejolak.

c. Rational/self-interest change strategy. Pendekatan in mengutamakan penyampaian keuntungan kepada pelaku resistensi apabila mereka menerima kebijakan terkait sehingga mereka tertarik dan lembut untuk menerima kebijakan atau perubahan.

Berdasarkan hasil analisis pada bagian ini, dapat dikatakan bahwa strategi penanganan resistensi adalah sangat beragam. Strategi penanganan sangat bergantung kepada identifikasi penyebab resistensi. Oleh karena itu tahapan mengidentifikasi penyebab resistensi adalah suatu hal yang sangat vital untuk menyusun strategi penanganan resistensi. Berikut rangkuman strategi berdasarkan kajian teori:

a. Ekonomi, strategi ini amat lekat dengan kebijakan finansial. Seperti negosiasi kompensasi, ganti rugi, dan metode lain yang bersifat keuangan.

b. Sosial, strategi ini adalah dengan memperbanyak sosialisasi dan komunikasi dengan masyarakat. Diskusi dan perlibatan masyarakat sangat dibutuhkan. Pendekatan ini membutuhkan ahli komunikasi, sosial, bahkan psikologi agar bisa mendapatkan kepercayaan dari masyarakat.

c. Lingkungan, pendekatan ini mengutamakan fokus terhadap penyelamatan lingkungan. Bisa dengan meningkatkan kualitas teknologi suatu kebijakan pembangunan agar keselamatan lingkungan bisa dijaga.

d. Pengambilan kebijakan atau politik kebijakan, pendekatan ini adalah dengan menggunakan kekuatan kekuasaan. Terdapat banyak kasus dimana ketegasa pemerintah diperlukan seperti pada kasus dimana memang masyarakat bersalah sehingga tidak diperlukan solusi lain selain bertindak tegas. Pendekatan ini harus digunakan pada saat yang tepat untuk menjaga stabilitas hubungan pemerintah dan masyarakat. Pendekatan ini juga bisa dengan menunda hingga saat yang tepat atau memindahkan lokasi kebijakan.

\subsection{Pemetaan Gerakan Resistensi Kebijakan Pembangunan}

Dengan agar hasil analisis bisa tergambarkan dengan baik, peneliti membuat sebuah mind mapping. Gambaran ini hanyalah hasil representative dari peneliti, adapun inti pembahasan terdapat pada penjelasan pada analisis diatas, sehingga mind mapping yang ditampilkan adalah murni hasil penggambaran peneliti yang bersifat subjektif.

Berikut mind mapping proses gerakan resistensi kebijakan apabila gagal ditangani dengan baik:

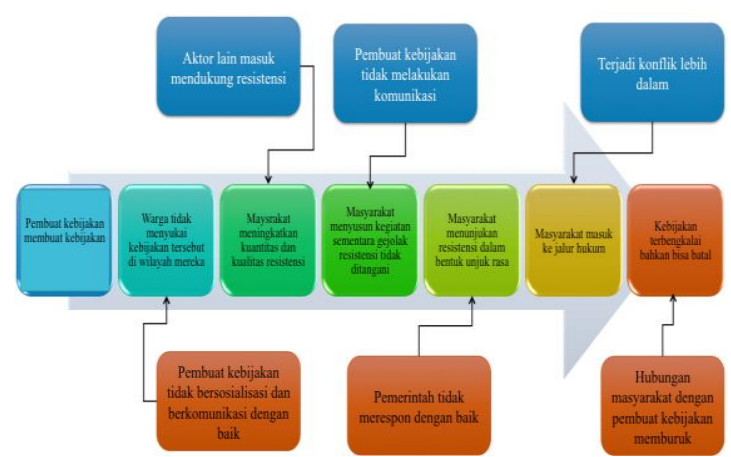

Gambar1. Mind mapping proses gerakan resistensi kebijakan apabila gagal ditangani dengan baik

\section{Penutup}

Sebagai penutup akan disajikan kesimpulan dari hasil penelitian. Serta akan disampaikan pula saran yang didasarkan pada hasil kesimpulan. Saran dalam hasil penelitian ini diharapkan dapat bermanfaat bagi pemerintah dan beberapa pihak sebagai masukan atau dasar pengambilan. Hal ini agar bisa dipertimbangkan oleh pemerintah kabupaten Indragiri Hilir.

\subsection{Kesimpulan}


Dari serangkaian pengolahan data dan analisa yang dilakukan pada penelitian ini dapat ditarik kesimpulan sebagai berikut:

a. Gerakan Resitensi memiliki beragam bentuk yang beragam tergantung kasus dan karakter masyarakat. Adayang berbentuk tersembunyi, unjuk rasa spontan, hingga yang teroganisir.

b. Gerakan resistensi tidak hanya akan memberikan dampak negative kepada pembuat kebijakan akan tetapi bisa juga berdampak kepada seluruh pelaku yang terlibat.

c. Soslialisasi dan komunikasi adalah hal yang sangat menentukan guna mengontrol laju gerakan resistensi

d. Dalam kajian literatur ini dijelaskan bahwasanya isu lingkungan, sosial, dan ekonomi menjadi isu utama yang kerap diangkat dalam gerakan resistensi.

e. Resistensi memiliki dampak negatif dan positif, namun dampak positif tidak selamanya bisa diterima apabila dampak negatif tidak ditangani.

f. Titik yang harus menjadi fokus perhatian adalah penyebab lahirnya gerakan resistensi wilayah kasus. Setiap kasus resistensi harus ditangani sesuai dengan penyebab resistensi sehingga setiap kasus harus ditangani dengan cara yang berbeda pula.

g. Penelitian ini juga mengambil kesimpulan bahwa aktor yang terlabat sangat beragam tergantu kasus, lokasi, dan kondisi masyarakat.

h. Salah satu kekhasan resistensi adalah lahirnya konflik. Umumnya konflik akan terjadi antara pembuat kebijakan dan masyarakat penerima kebijakan namun tidak menutup kemungkinan untuk lahirnya konflik di antara aktor lain.

\subsection{Rekomendasi}

Dari serangkaian analisa dan hasil kesimpulan yang dilakukan pada penelitian ini peneliti memberikan rekomendasi kepada pembuat kebijakan pada gerakan resistensi yang dalam hal ini ditujukan kepada Pemerintah Kabupaten Indragiri Hilir. Pembuat kebijakan dalam hal ini adalah bisa berasal dari kalangan pemerintahan, pemilik perusahaan, dll. Berikut rekomendasi untuk pihak pembuat kebijakan:

a. Kepada pihak pembuat kebijakan direkomendasikan untuk mempertimbangkan gerakan resistensi sebelum meresmikan kebijakan. Hal ini dilakukan agar dampak-dampak negatif

b. Pihak pembuat kebijakan harus menjadikan komunikasi dan sosialisasi sebagai hal penting dalam membuat kebijakan. Hal ini dikarenakan kepercayaan yang buruk dari masyarakat terhadap pembuat kebijakan akan berdampak pada terjadinya resistensi yang besar sekalipun kebijakan yang diambil adalah benar dan sesuai dengan kondisi yang ada.

c. Pembuat kebijakan harus cepat tanggap merespon resistensi atau penolakan. Respon yang ditunda atau terlambat akan menjadikan gerakan resistensi semakin besar sehingga hubungan antara masyarakat dan pembuat kebijakan menjadi tidak harmonis dan semakin sulit mengimplementasikan kebijakan.

\subsection{Keterbatasan Studi}

Studi ini mempunyai keterbatasanketerbatasan yakni:

a. Penelitian ini baru menjelaskan gerakan resistensi berdasarkan kajian teori saja belum berdasarkan studi kasus tersendiri dan kajian teori atau pustaka ini dijadikan dasar persiapan untuk menghadapi gerakan resistensi

b. Penilitian ini meneliti tentang gerakan resistensi secara teori atau umum sehingga tidak bisa membandingkan antar kasus di dunia nyata

c. Masyarakat yang menjadi pelaku gerakan resistensi pada penelitian ini merupakan masyarakat dengan karakteristik masyarakat perkotaan sehingga ada kemungkinan memiliki perbedaan dengan masyarakat perdesaan.

d. Penelitian ini tidak meneliti tentang kerugian pembuat kebijakan secara ekonomi. 


\subsection{Studi Lanjutan} yakni:

Studi lanjutan yang dapat dilakukan

a. Faktor-faktor yang mempengaruhi kegagalan sosialisasi kebijakan pembangunan di salah satu kasus di Kabupaten Indragiri Hilir

b. Perbandingan dinamika gerakan resistensi pada masyarakat perdesaan dan perkotaan

c. Dampak finansial akibat gerakan resistensi terhadap sebuah kebijakan

d. Manajemen konflik yang terjadi di dalam sebuah kasus resistensi kebijakan

\section{Daftar Pustaka}

[1] Agocs, C. (1997). Institutionalized resistance to organizational change: Denial, inaction, and repression. Journal of Business Ethics

[2] Ahmed, P.K., Lim, K.K. dan Loh, A.Y.E. 2002,

[3] Anderson, James E. 2003. Public Policymaking. Fifth. USA : Houghton Miffin Company.

[4] Boyer Marcel. 2013. how can the NIMBY sindrome be avoided. Canada: University of Montreal

[5] Boyer Marcel. 2013. how can the NIMBY sindrome be avoided. Canada: University of Montreal

[6] Capra, F. (2002). Jarring-Jaring Kehidupan Visi Baru Epistemologi dan Kehidupan. Terjemahan oleh Saut Pasaribu. Yogyakarta: Fajar Pustaka Baru

[7] Carol Hager, Mary Alice Haddad. 2015. NIMBY Is Beautiful: Cases of Local Activism and Environmental Innovation around the World. New York: Berghahn Books

[8] Danial, Wasriah. 2009. Metode Penulisan Karya Ilmiah. Bandung: Laboratorium Pendidikan Kewarganegaraan UPI. Darmawan, D

[9] De Bono, Silvio. 2006. Creating Growth from Change. Maastricht School of Management (unpublished) pg. 91

[10] Der Haar, D.V. dan Hosking, D.M. 2004. Evaluating Appreciative Inquiry: a relational constructionist perspective. Human Relations, 57, 8, 1017-1036.

[11] Kate, Julie, dan Diana Thrush. 2006. The limitations of the NIMBY concept for understanding public engagement with renewable energy technologies: a literature review. Guildford: University Of Surrey.

[12] Learning Through Knowledge Management. London: Butterworth Heinamann

[13] Raths, David. 2006. Leading through Change. Network World. Framingham: Mar 6, 2006. Vol. 23, Iss. 9; pg. 46.

[14] Scott, James, S. 2012. Senjata OrangOrang Kalah : Bentuk Perlawanan Sehari-hari Kaum Tani. Terjemahan oleh Sajogyo. Jakarta: Yayasan Obor

[15] Siagian, Sondang. 1994 Administrasi Pembangunan. Jakarta: Gunung Agung

[16] Sugiyono. 2012. Metode Penelitian Kuantitatif Kualitatif dan R\&D. Bandung: Alfabeta. 